\title{
Peningkatan Pemahaman Dan Keterampilan dalam Pengurusan Jenazah Bagi Masyarakat Mejing, Ambarketawang, Gamping
}

\author{
Muh. Endriyo Susila ${ }^{1}, J_{u a n d a}{ }^{2}$, Wardanik $^{3}$ \\ Program Studi Hukum, Fakultas Hukum, Universitas Muhammadiyah Yogyakarta \\ Email:endriosusilo@umy.ac.id \\ DOI: 10.18196/ppm.34.278
}

\begin{abstract}
Abstrak
Pemahaman dan keterampilan dalam pengurusan jenazah dibutuhkan oleh masyarakat pedesaan yang bersifat komunal. Berbeda dengan masyarakat di perkotaan yang bisa dan biasa menggunakan jasa layanan pengurusan jenazah yang disediakan oleh yayasan yang khusus bergerak dalam bidang itu, masyarakat pedesaan mengatasi sendiri keperluan pengurusan jenazah di antara mereka secara bergotong royong. Tulisan ini bertujuan menjelaskan upaya yang telah dilakukan untuk meningkatkan pemahaman dan keterampilan terkait pengurusan jenazah di beberapa lokasi di dusun Mejing, desa Ambarketawang, Kecamatan Gamping. Metode yang digunakan untuk mewujudkan pemahaman dan keterampilan dimaksud adalah melalui pengajian dan pelatihan. Pelaksanaan kegiatan mendapat sambutan cukup antusias dari warga masyarakat meski dilaksanakan dalam suasana keprihatinan akibat pandemik Covid-19. Kegiatan pelatihan yang sudah terlaksana bisa menjadi model untuk peningkatan pemahanan dan keterampilan dalam pegurusa jenazah di lokasi lain di wilayah Desa Ambarketawang.
\end{abstract}

Kata Kunci: Pelatihan, Pengurusan Jenazah, Mejing

\section{PENDAHULUAN}

Setiap yang bernyawa pasti akan merasakan mati,4 demikian juga dengan manusia. Berita lelayu (berita duka terkait meninggalnya seseorang) terdengar hampir setiap hari melalui pengeras suara di masjid-masjid. Kematian merupakan realitas sehari-hari di tengah-tengah masyarakat. Meski begitu, kematian bukan sekedar fenomena sosial biasa, namun di dalamnya terkandung dimensi moral dan agama. Oleh karena itu hal-hal yang berkaitan dengan peristiwa kematian hendaknya tidak sekedar dilihat dengan perspektif sosial semata, melainkan harus pula dilihat dan didekati dengan pendekatan moral dan agama.

Setiap agama memiliki caranya sendiri-sendiri dalam mengurus jenazah. Meskipun berbeda cara dalam menyelenggarakan pengurusan jenazah, setiap agama memiliki pandangan yang kurang lebih sama bahwa kematian adalah peristiwa besar yang terkandung nilai-nilai sakralitas di dalamnya. Oleh karena itu, pengurusan jenazah hendaknya diselenggarakan dengan cara yang sebaik-baiknya sesuai ajaran agama masing-masing.

Dalam Islam, pengurusan jenazah merupakan salah satu kewajiban yang bersifat kolektif yang dalam bahasa agama disebut dengan istilah 'fardlu kifayah'. Kewajiban kolektif dalam hal ini adalah bahwa tidak setiap orang harus melakukan kewajiban tersebut, melainkan cukup dengan

\footnotetext{
${ }^{1}$ Dosen Program Studi Ilmu Hukum, Fakultas Hukum Universitas Muhammadiyah Yogyakarta (endriosusilo@umy.ac.id)

${ }^{2}$ Dosen Program Studi Akuntansi, Fakultas Ekonomi, Universitas Muhamadiyah Yogyakarta

${ }^{3}$ Mahasiswa Program Studi Ilmu Hukum, Fakultas Hukum Universitas Muhammadiyah Yogyakarta

${ }^{4}$ Lihat Al-Quran Surah 'Ali 'Imran ayat 185.
} 
perwakilan. Dengan demikian maka, kewajiban seseorng telah gugur jika telah ada orang lain yang melaksanakannya. Namun jika tidak ada seorangpun yang melaksanakan, maka dosanya dibebankan kepada seluruh kaum muslimin.5

Dengan karakter yang demikian itu, maka fardhu kifayah dapat pula diartikan sebagai sebuah bentuk kewajiban yang bersifat publik, dalam arti pengurusan jenazah merupakan kewajiban yang dibebankan kepada masyarakat secara umum. Karena berkarakter publik semacam itu, maka pengurusan jenazah memerlukan campur tangan pihak yang berkuasa (pemerintah). Campur tangan pemerintah diperlukan guna memastikan terpenuhinya kewajiban tersebut.

Pengurusan jenazah secara baik dan benar sesuai ajaran agama dapat mendatangkan ketenteraman tidak hanya bagi ahli keluarga, tetapi juga warga masyarakat secara umum. Karena menyangkut kepentingan masyarakat luas, pemerintah desa memberikan perhatian khusus pada soal pengurusan jenazah, terutama terhadap jenazah yang beragama Islam. Hal ini dapat dimaklumi mengingat, Islam adalah agama yang dianut oleh mayoritas penduduk di Indonesia. Hal itu diwujudkan dengan mengangkat atau menempatkan seorang modin di setiap pedukuhan. Modin adalah petugas yang diangkat dan diberi tugas untuk mengurus segala hal yang berkaitan dengan pengurusan jenazah bagi anggotaa masyarakat yang ada di wilayah tugasnya.

Dalam ajaran Islam kewajiban terhadap jenazah ada empat macam yaitu memandikan, mengafani, menyolatkan serta menguburkan. Di antara empat kewajiban tersebut. Penguburan jenazah merupakan bagian akhir dan merupakan puncak acara pengurusan jenazah. Penguburan jenazah biasanya diawali dengan sebuah upacara pemberangkatan jenazah yang biasanya dipimpin oleh seorang modin.

Selain memimpin upacara pemberangkatan jenazah ke tempat pemakaman, kadang kala modin juga dilibatkan dalam proses-proses sebelumnya seperti memandikan serta mengafani jenazah. Pelibatan modin masih berlanjut bahkan setelah jenazah selesai dimakamkan. Biasanya modin diminta untuk memimpin acara tahlilan, khususnya pada tiga hari pertama sejak jenazah dimakamkan. Tradisi semacam itu dipraktikkan secara meluas oleh masyarakat di pedukuhan Mejing yang dipilih sebagai sasaran dari kegiatan pengabdian yang diusulkan melalui skema Pengabdian Kemitraan Masyarakat (PKM) ini.

\section{PERMASALAHAN}

Ada satu orang modin yang ditugaskan di wilayah Dusun Mejing Lor. Meski seorang modin memiliki wilayah kerja yang cukup luas, sejauh ini seluruh kebutuhan layanan pengurusan jenazah relatif bisa dihandel oleh modin. Hal ini karena beberapa aspek pengurusan jenayah teknisnya dikerjakan oleh warga setempat. Misalnya, proses memandikan jenazah, modin tidak terjun secara langsung, tetapi hanya memandu dan mengawasi saja. Sementara kerja teknis dihandel oleh warga masyarakat, biasanya anggota keluarga atau tetangga dekat.

\footnotetext{
${ }^{5}$ Lihat artikel berjudul "Pengertian Fardhu Kifayah dan Fardhu 'Ain Lengkap dengan Contohnya", dapat diakses di http://www.islamianews.com/2015/01/pengertian-fardlu-kifayah-dan-chontohnya.html pada tanggal 07 Agustus 2019.
} 
Meski secara empiris jarang terjadi, tapi jumlah modin yang hanya satu orang tersebut berpotensi menimbulkan masalah di tingkat praktis. Suatu ketika bisa muncul persoalan manakala modin berhalangan, padahal saat itu jasanya sedang dibutuhkan. Tidak mudah mencari pengganti yang siap mengambil alih tugas modin tersebut. Masalah lainnya adalah berkaitan dengan faktor kesesuaian jenis kelamin. Modin yang berjenis kelamin laki-laki harus juga mengurus jenazah dari jenis kelamin perempuan.

Memandikan jenazah adalah perkara yang bersifat privat. Secara hukum, aurat jenazah perempuan tidak boleh terlihat oleh laki-laki, kecuali suaminya atau jika jenazah adalah anak perempuan yang belum baligh. ${ }^{6}$ Dalam praktik di wilayah Mejing, modin ikut hadir dalam proses memandikan jenazah baik jenazah laki-laki maupun jenazah perempuan. Seperti yang terjadi belum lama ini pada kasus kematian Nyonya Irianti warga RT 03/RW 01 Mejing Lor, modin berada di area penyucian jenazah. ${ }^{7}$

Laki-laki yang ikut terlibat dalam proses memandikan jenazah tersebut tidak hanya modin seorang diri, melainkan ada beberapa laki-laki lain yang ikut membantu proses memandikan. Beberapa laki-laki lain tidak melakukan apa-apa selain menonton saja. Keberadaan modin di area privat tersebut masih bisa dimaklumi, tetapi keberadaan laki-laki lain apalagi yang sekedar menonton saja tidak dapat dibenarkan menurut ajaran Islam. Sayangnya, pemandangan demikian sudah lumrah terjadi di wilayah pedukuhan Mejing, dan mungkin di wilayah pedukuhan lain pun tidak jauh berbeda.

Meskipun dalam keadaan tertentu keberadaan modin di area memandikan jenazah perempuan bisa ditolerir, tetapi sebenarnya ada dampak negatif yang mungkin kurang disadari. Keberadaan modin laki-laki di area privat tersebut seolah memberi justifikasi bahwa warga masyarakat lainnya yang berjenis kelamin laki juga boleh berada di area yang sama. Jika hal demikian terus dibiarkan, maka upaya untuk menjaga kesucian, kehormatan jenazah perempuan serta menjaga sakralitas proses penyucian jenazah akan mengalami kendala

Berhubungan dengan hal tersebut, perlu kiranya diupayakan adanya peningkatan pemahaman warga masyarakat Mejing Lor berkaitan dengan pengurusan jenazah sesuai ajaran agama Islam. Untuk memberi pemahaman yang benar khususnya mengenai hukum yang mengatur tentang tata cara memandikan serta mengafani jenazah. Pemahaman yang merata di kalangan warga masyarakat dapat mengurangi tingkat ketergantungan pada modin. Modin bisa lebih fokus menangani urusan lain seperti memimpin upacara pemberangkatan jenazah, sedangkan urusan memandikan dan mengafani jenazah bisa ditangani sendiri oleh pihak keluarga, atau pun jika tidak pelaksanaannya bisa diatur sedemikian rupa sehingga jenazah perempuan dimandikan dan dikafani oleh tetangga atau handai tolan yang perempuan saja.

\footnotetext{
${ }^{6}$ Lihat "Memandikan dan Mengkafani Jenazah", diunduh dari https://muslim.or.id/43876-fikih-pengurusan-jenazah1-memandikan-dan-mengkafani.html pada tanggal 07 Agustus 2019

${ }^{7}$ Pengusul skema Pengabdian Kemitraan Masyarakat mengetahui sendiri bahwa proses memandikan jenazah melibatkan banyak orang, dan sebaiannya laki-laki.
} 


\section{METODE}

Upaya meningkatkan pemahaman dan ketrampilan warga masyarakat terkait pengurusan jenazah dilakukan dengan memberikan penyuluhan dan pelatihan. Penyuluhan tentang hukumhukum terkait memandikan dan mengafani jenazah bisa dikemas dalam bentuk pengajian seperti sudah biasa dikenal. Sedangkan hal-hal yang sifatnya memberi ketrampilan teknisnya dilakukan melalui metode pelatihan.

\section{PELAKSANAAN DAN PEMBAHASAN}

a. Selayang Pandang tentang Dusun Mejing Lor

Dusun Mejing yang diajukan sebagai lokasi sasaran kegiatan pengabdian berada di wilayah Desa Ambarketawang, Kecamatan Gamping, Kabupaten Sleman. Desa Ambarketawang dibagi menjadi 13 pedukuhan, terdiri dari: Bodeh, Depok, Gamping Kidul, Gamping Lor, Gamping Tengah, Kalimanjung, Mancasan, Mejing Kidul, Mejing Lor, Mejing Wetan, Patukan, Tlogo dan Watu Langkah. ${ }^{8}$

Secara administratif, masing-masing dukuh dipimpin oleh seorang Kepala Dukuh. Seorang kepala dukuh melayani warga masyarakat yang terbagi-bagi dalam satuan yang disebut Rukum Warga (RW). Rukun Warga masih dibagi-bagi lagi dalam satuan yang lebih kecil yang dinamakan Rukun Tetangga (RT). Di wilayah Dusun Mejing Lor, satu RT bisa membawahi lebih dari 70 keluarga, seperti yang terjadi di RT 03 RW 01 Mejing Lor.

Pemilihan Dusun Mejing Lor sebagai sasaran dari kegiatan pengabdian didasarkan pada beberapa alasan, baik alasan teknis, demografis maupun alasan budaya dan agama. Secara teknis, kegiatan pengabdian di Dusun Mejing Lor lebih mudah dilakukan karena lokasinya cukup dekat dengan kampus, dan pengusul sendiri berdomisili di wilayah tersebut, yaitu di RT O3/RW 01 Mejing Lor. Secara demografis, Mejing Lor termasuk dusun yang padat penduduk. Ada banyak pendatang yang menetap di Dusun Mejing Lor, baik yang tinggal di area perkampungan, maupun di kompleks-kompleks perumahan. Ada 2 kompleks perumahan dan beberapa komplek kaplingan di wilayah Dusun Mejing Lor.

Dari aspek budaya warga masyarakat Mejing secara umum masih bersifat tradisional. Nilainilai tradisi masih kuat dipraktikkan di kalangan warga. Menurut pengamatan pengusul yang sudah menetap lebih dari sembilan tahun di wilayah tersebut, masyarakat Mejing Lor masih mengamalkan tradisi-tradisi yang kurang sesuai dengan ajaran agama (dalam hal ini Islam), termasuk yang berhubungan dengan pengurusan jenazah.

b. Pelaksanaan Kegiatan dan Pembahasan

Pengajian dan Pelatihan Perawatan Jenazah terselenggara atas kerja sama Tim Pengabdian Masyarakat UMY yang terdiri dari M. Endriyo Susila, SH, MCL, PhD (Dosen FH, Juanda Sag, MA (Dosen FE) dan Wardanik (Mahasiswa FH) dengan pihak Pimpinan Ranting Muhammadiyah (PRM) Mejing.

\footnotetext{
${ }^{8}$ Ambarketawang, Gamping, Sleman, diunduh dari

https://id.wikipedia.org/wiki/Ambarketawang,_Gamping,_Sleman pada tanggal 07 Agustus 2019
} 
Pengajian dan pelatihan pengurusan jenazah telah berhasil diselenggarakan di tiga lokasi, yaitu Masjid Al-Hidayah, Masjid Al-Barokah, dan Masjid Baitul Mutaqien. Tiga kegiatan tersebut dipandu oleh seorang fasilitator bernama Ustadz Umar Said Prawoto dari RSU PKU Muhammadiyah Gamping.

Pengajian dan Pelatihan Perawatan Jenazah di Masjid Al-Hidayah dilaksanakan pada tanggal 23 Agustus 2020 pukul 20.00-22.30 WIB, di Masjid Al-Barokah dilaksanakan pada tanggal 15 September 2020 pukul 20.00-22.00 WIB, sedangkan di Masjid Baitul Mutaqien dilaksanakan pada tanggal 8 November 2020 pukul 20.00-22.00 WIB, dengan tetap memperhatikan protokol kesehatan. Kegiatan tersebut, baik di masjid Al Hidayah, masjid Al-Barakah, maupun masjid Baitul Mutaqien dihadiri dan diikuti secara antusias oleh jamaah laki-laki maupun jamaah perempuan. Hal ini menunjukkan bahwa kebutuhan jamaah akan pemahaman dan ketrampilan pengurusan jenazah cukup tinggi. Dengan adanya kegiatan tersebut, diharapkan para jamaah Masjid Al-Hidayah, Masjid Al-Barokah, serta Masjid Baitul Mutaqien memahami tata cara pengurusan jenazah mulai dari cara memandikan jenazah sampai dengan memakamkan jenazah menurut syariat islam dan diharapkan seluruh jamaah peserta pelatihan bisa mengaplikasikannya.

\section{PENUTUP}

Berdasarkan uraian tersebut, dapat disimpulkan bahwa kegiatan pengajian dan pelatihan perawatan jenazah seperti yang telah diselenggarakan di masjid Al-Hidayah, masjid Al-Barakah, maupun masjid Baitul Mutaqien merupakan cara yang cukup menarik dan efektif untuk meningkatkan pemahaman dan keterampilan warga Mejing terkait pengurusan atau perawatan jenazah. Kegiatan semacam ini perlu dilanjutkan di masjid-masjid lainnya dalam wilayah pedukuhan Mejing agar pemahaman terkait perawatan atau pengurusan jenazah, khususnya dalam hal memandikan dan mengafani tersebar secara merata.

\section{DAFTAR PUSTAKA}

Al-Quran

Ambarketawang, Gamping, Sleman, diunduh dari https://id.wikipedia.org/wiki/Ambarketawang,_Gamping,_Sleman pada tanggal 07 Agustus 2019.

"Pengertian Fardhu Kifayah dan Fardhu 'Ain Lengkap dengan Contohnya", dapat diakses di http://www.islamianews.com/2015/01/pengertian-fardlu-kifayah-dan-chontohnya.html pada tanggal 07 Agustus 2019.

"Memandikan dan Mengkafani", diunduh dari https://muslim.or.id/43876-fikih-pengurusanjenazah-1-memandikan-dan-mengkafani.html 